\title{
Factor Analysis of the Interest in the Work of Socially Important Institution
}

\author{
Rudaleva I.A. \\ Kazan Federal University, Institute of Management, Economics and Finance, Kazan, 420008, Russia \\ Email address: rudiran@mail.ru. \\ Kabasheva I.A.
}

Kazan Federal University, Institute of Management, Economics and Finance, Kazan, 420008, Russia

Doi:10.5901/mjss.2014.v5n24p317

\begin{abstract}
The article presents the research results in which identified interest determinants of employed health workers. Stable and peaceful relations with colleagues are an important factor of interest, whereas frequent disagreements - have negative influence on employee interests in work activity. Found a significant direct relationship between work activity interest and the wages amount. Lone workers have a low level of interest in work activity. A significant factor was satisfaction with work process, because it's an implementation result of the employment interests of employees. Availability awards and bonuses to wages, overtime pay and it's payment determines to a lesser extent the employee interests in work activity.
\end{abstract}

Keywords: job performance, job satisfaction, workforce, degree of interest

\section{Introduction}

Workforce interest is provided with the system of interrelated forms and tools of motivation increasing satisfaction by various characteristics of career development. Thus in the modern sense of the term, the development of Workforce motivation particularly means to establish conditions for job involvement and to heighten Workforce interest in efficiency and quality of work. It gives the possibility to achieve self-actualization and to support the professional development needs improving the productivity and profitability of the organization.

Generally it should be noted that raising the interest of Workforce by the motivation is explained by the theory of motivation. Modern theories of motivation are divided into 2 types: procedural and content. Procedural theories of motivation are based on the fact the person distributes its effort to achieve the desired results and why a person makes this or that type of behavior. [1,2,3] The motivation of employees to complete a task is affected by the reward they expect to receive. It explains direction in the behavioral process. It does not attempt to explain what motivates individuals, but rather how they make decisions to achieve the result they want.

On the contrary content theories of motivation primarily examine those needs of people that motivate them to act, especially when defining volume and contents of work. $[4,5]$

Without criticizing the theories of motivation it should be mentioned that the interest in work acts as a significant factor in both theories. A lot of research has been done to study it.

Modern version of the process theory of motivation is presented by Daniel Pink. [6] He suggests switching from external stimuli motivation (among which material reward is the main one) to internal - the most important of which is the full disclosure of human interest in job performance. According to Pink, in the information age monetary rewards, bonuses and other forms of material incentives are either useless or harmful to workers and the enterprise. Material compensation is effective when there are algorithmique tasks.

According to McKinsey \& Co in the U.S. only $30 \%$ of new jobs are associated with algorithmic work, and $70 \%$ of people have jobs with elements of creativity and analysis. [6] He lists three elements of the motivation formula: autonomy, mastery, and purpose. In situations where people are paid fairly, this trio drives, engages, and stimulates them to do the best of their job. It makes sense that old-school organizational and personal frameworks of productivity just do not cut it in this age when knowledge work, creativity, and problem-solving are required to stand out and succeed. He considers employing only those workers who have strong intrinsic motivation - curiosity and independence.

Certainly Pink's theory is impossible in modern Russia, where decent wages is viewed more as a "hygienic", than a motivational factor: heuristic activities (high-tech industries, inventions, applied sciences, research and development, etc.) 
are not developed. There is also low productivity, shortage of skilled workers and management in enterprises, etc. However we consider that the growth of Russian economy through building the Information society will make these postulates actual.

There is a similar approach towards question of theories of motivation in D. McGregor fundamental work "The Human Side of Enterprise" (1957), where he convincingly proved that "Effort in work is as natural as work and play" and that the capacity to use a high degree of imagination, ingenuity and creativity in solving organisational problems is widely, not narrowly, distributed in the population and that under particular conditions, " ...people usually accept and often seek responsibility". [7]

In self-determination theory (SDT) of human motivation and personality of Edward L. Deci and Richard M. Ryan, a person's ability to experience interest is considered to be fundamental in his nature. [8] According to scientists this ability should be only developed and strengthened. Universality of human needs in the competence, autonomy and relationship satisfaction are of priority need. Only in this case we are motivated, most productive and happy.

Similar empirical results were obtained by researchers at Cornell University who studied 320 small businesses, half of which were based on the internal interest of the workers, provided them with greater autonomy, while the other half was based on the rigid vertical management. Indicators of growth - oriented enterprises interest of workers, were four times higher than the corresponding figures of firms focused on monitoring. Indicators of labor turnover were three times less. [9]

Interest and job satisfaction, in terms of temporary employees is researched by Ellingson J. E., Gruys M. L. and Sackett P. R. Analysing specifics of the factors influencing job satisfaction of temporary workers, they come to the conclusion that first of all it is caused, by the degree of voluntary or involuntary consent for temporary work. [10]

In 2011 global research of employee engagement conducted by the GfK get adverse results about the low degree of employee's interest among working-age population. 30,556 working adults from 29 European and American countries, including Russia and the United States, were surveyed by GfK. Demographic data of each country (industry, gender, age) were obtained. According to the results young workers all over the world are not interested in employment: it is not only engagement, they are stressed at work, what can lead to problems in the management and to slower development, both for companies and for economics in general. [11]

Survey results showed polarization of the labor market around the world. On the one hand, there; disappointed people of ages 18-29 and on the other, their senior co-workers. Although younger employees usually are not responsible at work, it is this group that has the highest percentage of employees "often" or "almost always" feeling anxious about work-life balance, overtime work and their health.

Confirmation of this research is the data of consulting firm McKinsey\&Co. These results show that only 2-3\% of labor force actively involved and interested in work. [12]

Low employee satisfaction leads to the development of opportunism. [13]

\section{Data and Methodology}

Information base and research methods are presented. The basis of the data analysis was employee survey data of Almetievsk city hospital in the Republic of Tatarstan. Data were combined into one array and used as a basis for calculations of regressions. Total number of observations is 152.

In our research health care workforce interest in job performance is analyzed by the following question: "Are you interested what you do at work?" (five-point scale, where 1-yes, 2-more yes than not, 3-is difficult to answer , 4-more no than yes, 5-no). We consider that this question allows assessing the adequacy of the content of job performance and professional interests. This means we assess workforce interest in the content and effectiveness of job performance.

Model. To estimate the parameters of interest in professional performance the following equation was used:

$Y J S=\alpha+\beta \cdot\left(x_{i}\right)+u^{*}$ (1)

where YJS - the interest in professional performance;

a-constant

$\beta \cdot\left(x_{i}\right)$ - matrix of characteristics

$u^{*}$ - components, reflecting the influence of factors not accounted for in the model.

Matrix of characteristics of the interest in professional performance $\beta \cdot\left(x_{i}\right)$ includes information: Do you have a good relationship with the members of workforce (colleagues)?; Are you satisfied with the value of your salary (remuneration of labour)?; Do you get uplifts apart from your salary (premiums, bonuses)?; Does professional activity give you pleasure? Do you often have disagreements with colleagues about work process?; Are you satisfied with job 
performance in workplace?; How do you assess the relation of your organization employees to their work conditions? Etc.

\section{Discussion}

We studied the assessment of health care workforce interest in job performance according the gender. Among 152 interviewed of Almetievsk clinical hospital workforce 69, 7\% (106 people) were women and 30,3\% (46 people) were men.

Factors of interest in job performance.

We examine how different factors affect the interest of health care workforce interest degree in job performance Table 1 provides an assessment of the importance of factors affecting interest.

Table 1. OLS model of employee job satisfaction. We used 152 observations

\begin{tabular}{|c|c|c|c|c|}
\hline Variables & Coefficient & tandard Errc & t-statistics & P-value \\
\hline const & 0,620925 & 0,321703 & 1,9301 & 0,05557 \\
\hline Do you have a good relationship with the members of workforce (colleagues)? (v12) & 0,398013 & 0,0700059 & 5,6854 & $<0,00001$ \\
\hline Are you satisfied with the value of your salary (ren & 0,211384 & 0,0584685 & 3,6153 & 0,00041 \\
\hline Jart from your salary (premiums, bonuses)? (v15) & 0,284193 & 0,0589848 & 4,8181 & $<0,00001$ \\
\hline Does $\mathrm{p}$ & 0,364985 & 0,069 & 5,2673 & $<0,000011^{\star \star}$ \\
\hline Do yo & $-0,254001$ & & $-4,1456$ & 0,00006 ** \\
\hline \begin{tabular}{|l}
$\begin{array}{l}\text { Are you satisfied with job performance in workplace? } \\
\text { (v26) }\end{array}$ \\
\end{tabular} & $-0,264937$ & 0,067084 & $-3,9493$ & 0,00012 \\
\hline Did the need of extra work hours appear in your organization last half a year? (v29) & & & & \\
\hline Are these extra work hours paid? (v30) & $-0,221865$ & 0,0580263 & $-3,8235$ & 0,00020 ** \\
\hline
\end{tabular}

Table 2. Analysis of the model parameters

\begin{tabular}{|l|c|}
\hline Indicators & Value \\
\hline Mean of Dependent Variable & 2,032895 \\
\hline Residual Sum of Squares & 85,68193 \\
\hline R-squared & 0,531372 \\
\hline F(8, 143) & 20,26822 \\
\hline log likelihood & $-172,1125$ \\
\hline Schwarz criterion & 389,4400 \\
\hline St. Deviate of Dep. Variable & 1,100378 \\
\hline Model bug & 0,774064 \\
\hline Corrected R-squared & 0,505155 \\
\hline P-value (F) & $3,00 \mathrm{e}-20$ \\
\hline Akaike Information Criteria & 362,2251 \\
\hline Hannan-Quinn Criterion & 373,2807 \\
\hline
\end{tabular}

We conducted a White's test for heteroskedasticity. Null hypothesis: heteroskedasticity is missing.

Test statistic: $L M=66,4961$.

$P$-value $=P($ Chi-square $(44)>66.4961)=0,0158387$.

Model analysis for multicollinearity showed its absence.

Table 2 data shows the importance of good interrelations of workforce. Data prove that stable, conflict-free and smooth relationship with co-workers is very important. This most important factor defines interest degree of employee in job performance (question 12). The analyses of the frequency of disagreements with co-workers shows complete picture of influence of intercollegiate relation on interest (v24). We found that frequent conflicts with co-workers affect negatively the employees interest in the workplace. That means the relationship between employees of health care institutions is a significant factor to form their interest in job performance. This is confirmed by the correlation coefficients (Table 3). 
Table 3. Correlation matrix, observations $1-1525 \%$ critical value (two-sided) $=0.1593$ for $n=152$

\begin{tabular}{|c|c|c|c|c|c|c|c|c|c|}
\hline v9 & $\mathrm{v} 12$ & $\mathrm{v} 14$ & $\mathrm{v} 15$ & $\mathrm{v} 16$ & $\mathrm{v} 24$ & $\mathrm{v} 26$ & $\mathrm{v} 29$ & $\mathrm{v} 30$ & \\
\hline 1,0000 & 0,4250 & 0,3308 & 0,2268 & 0,4881 & $-0,1869$ & 0,2061 & 0,1629 & 0,0304 & $\mathrm{v} 9$ \\
\hline & 1,0000 & 0,1662 & $-0,1713$ & 0,4241 & $-0,0642$ & 0,4265 & 0,0976 & 0,0904 & $\mathrm{v} 12$ \\
\hline & & 1,0000 & 0,4369 & 0,4362 & 0,1380 & 0,5427 & $-0,0102$ & 0,4916 & $\mathrm{v} 14$ \\
\hline & & & 1,0000 & 0,1772 & 0,2792 & 0,1978 & $-0,0455$ & 0,3528 & $\mathrm{v} 15$ \\
\hline & & & & 1,0000 & 0,0458 & 0,5513 & 0,0928 & 0,3157 & $\mathrm{v} 16$ \\
\hline & & & & & 1,0000 & 0,0368 & 0,0115 & 0,2013 & $\mathrm{v} 24$ \\
\hline & & & & & & 1,0000 & 0,0765 & 0,3412 & $\mathrm{v} 26$ \\
\hline & & & & & & & 1,0000 & 0,1998 & $\mathrm{v} 29$ \\
\hline & & & & & & & & 1,0000 & $\mathrm{v} 30$ \\
\hline
\end{tabular}

Now we discuss the factor of the job management (v26). According to results obtained, this factor contributes positively to workforce interest in job performance. In other words, the better is the teamwork management (schedule, task overload, workplace equipment, etc.) the higher is the workforce interest rate in the content and the results of their work.

Salary is a significant factor when forming the workforce interest in job performance. There is a direct connection between the salary and its size.

According to the data obtained, job satisfaction in a greater degree defines workforce interest in job performance than any other factors. We consider this is a result of the efficient management in Health Care workforce interest development and the factor of self-appraisal of their work. In this regard it is attractive in the practical application.

Extra bonuses (v15 - 0,2268), overwork (v29 - 0,1629) and its payment define the workforce interest in job performance in a less degree.

\section{Conclusion}

We described the Health Care workforce interest in job performance in terms of their sex, age, marital status, education and defined factors that affect the interest. Major tasks that were initially staged were solved during the model building. Our research reflects the most important aspect of Health Care workforce life, their interest in job performance.

\section{References}

Vroom V. (1964) Work and motivation. N.Y. Wiley, 334 p.

Vroom V. (1969) Industrial social psychology. The Handbook of social psychology. Vol 5. N.Y.: Addison-Wesley, pp. 200-208

Salmon W., Lawler E. and others. (2007) Corporate Governance. Published by Harvard Business Press, 224 p.

Herzberg F. (1966) Work and the nature of man. N.Y.: World Publishing Company, 184 p.

McClelland D. (1975) Power: The inner Experience. New York: Irvington

Pink H. (2011) Drive: The Surprising Truth About What Motivates Us. Penguin Group, 242 p.

McGregor D. (1957) The human side of enterprise. Adventures in Thought and Action. Proceedings of V-th Anniversary Convocation of the School of Industrial Management. MT: MIT, pp. 23-30

Ryan R., Deci E. (2000) Self-determination theory and the facilitation of intrinsic motivation, social development, and well-being. American Psychologist, Vol. 55, pp. 68-78

Baard P., Deci E., Ryan R. (2004) «Intrinsic Need Satisfaction: A Motivational Basis of Performance and Well-Being in Two Work Settings», Journal of Applied Social Psychology. Vol.34

Ellingson J., Gruys M., Sackett P. (1998) Factors related to the satisfaction and performance of temporary employees. Journal of Applied Psychology, 83, pp.913-921

American Institute of Public Opinion. Official web-site: www.gallup.com

Kirkland R. ed. (2009) What Matters? Ten Questions That Will Shape Our Future, McKinsey Management Institute, pp. 80

Bodrov O. Main causes of staff labor opportunism in organizations // Life Science Journal, 11(14), 2014, 400-408 